\title{
TRANSUMANISMUL - CONSIDERAȚII TEOLOGICE ȘI ETICE -
}

\author{
Mihail COMĂNOIU*
}

\begin{abstract}
Transhumanism. Theological and ethical considerations ${ }^{1}$. The current technological and biomedical discoveries operationalized by the trans-humanist ideology as argumentation for the biological immortality of human being, challenges the Christian theology to a deeper reflection of the meaning of death and life, as well as awareness of the responsibility towards its own nature, in order to protect human dignity. The transhumanism project aims to provide the hope of terrestrial immortality or at least the prolongation of life near the matusalemic ages. Such a generous offer brings with it many risks and challenges, at individual and community level. Analyzing the proposals made by the transhumanism we can ask ourselves: Can the human genome be subject of a process of editing or reediting? Does the improvement of physical, intellectual or moral capacities have a purely utilitarian character? The Christianity is faced with an ideology that outlines its own soteriology and eschatology. Even if the transhumanism does not aim to be a religion, there are some aspects that require a theological analysis. It inspires to peoples the idea that mortality is only a stage that will be overcome by the development of technology. The redemption of the death and the conquest of immortality with it, through various forms such as: genetic editing, human-machine hybridization or cyborg, transfer of the consciousness into a machine, are the interpretation keys of a salvation through matter, with the help of matter, but only in the plan of the potentialities of matter, without any desire to overcome matter.
\end{abstract}

“PhD Student, Faculty of Orthodox Teology „Justinian Patriarch”, at University of Bucharest, Bucharest, Romania.

${ }^{1}$ Realizat sub îndrumarea Pr. Prof. Univ. Dr. Ștefan Buchiu, care și-a exprimat acordul pentru publicare. 
Keywords: transhumanism, cyborg, human enhancement, technology, post human.

\section{Introducere: istorie și ideologie}

Odată cu dezvoltarea tehnologiilor și capacității lor de a interfera cu viața umană, apar ideologii care preamăresc dreptul autonomiei individului în definirea propriei individualități. Proiectul transumanist se înscrie în acest demers de a redefini umanitatea prin intermediul bioingineriilor, nano-tehnologiilor sau biochimiei, în vederea depășirii condiției umane naturale, a îmbunătățirii ei, a obținerii imortalității prin diverse tehnici sau a prelungirii existenței biologice. Transumanismul se dorește a fi astfel o mișcare transformatoare a existenței umane în mod radical. În acest context, lucrarea de față își propune să analizeze și să evalueze dacă transumanismul intră sau nu în contradicție cu antropologia creștină, fundamentată biblic, precum și cu soteriologia ortodoxă.

Una dintre definițiile mișcării transumaniste, căci aceasta evoluează, precizează că transumanismul este:

„o abordare interdisciplinară care ne ajută să înțelegem şi să evaluăm căile care ne vor permite să depășim limitele noastre biologice prin progresele tehnologiei. Transumaniștii caută să dezvolte posibilități tehnice pentru ca oamenii să trăiască mai mult timp şi mai sănătoşi, crescând totodată capacitățile lor intelectuale, fizice și emoționale"2.

Modalitățile prin care se încearcă să se ajungă la aceste rezultate sunt foarte diverse și privesc dezvoltarea capacităților ființei umane cu ajutorul următoarelor domenii de cercetare: tehnologii anti-îmbătrânire, interfață computer-creier, biotehnologii, inteligență artificială, nanotehnologii, inginerie genetică, clonare, clonare terapeutică, cyborg, robotică, interfață om-mașină, transferul minții etc.

O primă declarație a transumanismului apare în anul 2002, prin Word Transhumanist Association, fondată în anul 1998 de unul dintre cei mai importanți lideri ai mișcării, Nick Bostrom, care se va constitui ca o cartă comună a acestor mișcări. Precizez încă de la început faptul că, în

2 Ce este transumanismul? Versiunea 3.2, disponibil la: https://iatranshumanisme.com/transhumanisme/la-declaration-transhumaniste/questce-que-le-transhumanisme-version-3-2/ (consultat 02.07.2019). 
viziunea mea, transumanismul capătă mai multe dimensiuni importante: transumanism filosofic, transumanism tehnologic şi transumanism religios.

Termenul „transhumanism” are o istorie mai îndelungată, în anul 1957 fiind utilizat pentru prima dată de către Julien Huxley pentru a defini prin trans-uman voința omului de a-și depăși propriile limite biologice, precum și pentru a-și îmbunătăţi condițiile de viață. Evoluţia curentului de gândire este preluată de către Fereidoum Esfandiary, cunoscut sub numele de FM-2030, cel care va cataloga pe cei care vor urma teoriile propuse de el cu privire la redefinirea omului și a condiției sale drept „trans-umani”, în sensul în care aceștia s-ar afla într-o perioadă de tranziție, evoluție și transformare către o altă formă de umanitate ${ }^{3}$.

Progresul exponențial al tehnologiei este asistat îndeaproape de teoreticieni ai convergențelor posibile dintre om și mașină, în încercarea de a depăși condițiile umane. În acest demers se va înscrie în anul 1990 filosoful Max More, fondând Institutul Extropy și completând definirea transumanismului sub aspect filosofic. Pentru el, transumanismul este

„un partid filosofic având scopul de a ne ghida către o condiție postumană. Transumanismul împărtășește numeroase valori cu umanismul, printre care un respect al rațiunii și al științei, un atașament față de progres și o mare consideraţie pentru existența umană (sau trans-umană) în această viaţă...Transumanismul diferă de umanism prin faptul că el recunoaște și anticipează schimbările radicale ale naturii și ale posibilităţilor vieții noastre provocate prin diverse științe și tehnici”"

\section{Aspirațiile metafizice ale transumanismului. Transcendență și nemurire}

Voința de a ameliora propria viață și condiția umană în fața finitudinii este semnul unei căutări existențiale a sensului vieții. Pentru creștini, această dorință de obținere a perfecțiunii se realizează în Hristos, prin îndumnezeirea naturii umane de către Acesta. Teologia ortodoxă explică mântuirea în funcție de actele fundamentale instituite de Hristos

${ }^{3}$ Beatrice Jousset-Couturier, Le transhumanisme, Paris, Edit. Eyrolles, 2016, p. 12-13.

${ }^{4}$ Max More, Transhumanism: Towards a Futurist Philosophy, 1990, apud. Ibidem, p. $15-16$. 
prin întrupare, pătimire, moarte și înviere. Atunci când aceste căutări existențiale sunt secularizate și atee, mântuirea, ca formă de transcendere a condiției umane, capătă modalități de exprimare care în planul ideologiei transumaniste se traduc prin speranța transformării omului prin tehnologie în noi forme de uman, trans-uman sau post-uman. Noul om, modificat prin intermediul tehnologiilor $\mathrm{NBIC}^{5}$, nu s-ar mai supune astfel morții biologice, mai mult, va depăși în mod inimaginabil propria condiție, având capacităţi intelectuale, fizice și morale extraordinare.

Transumanismul, prin căutarea nemuririi, se înscrie într-un demers de transcendere cu perspective soteriologice și eshatologice. În acest sens, analizând declarația transumanistă a lui Nick Bostrom din anul 20016, observăm o abordare persuasivă, prin care se încearcă aderarea cititorului la un anumit crez. Ultima frază a acestui manifest se încheie cu o întrebare ce vizează identificarea sau asocierea la crezul anunțat anterior: „Are you a transhumanist?", enunțând ulterior epifania sau revelarea actualității acestei ideii - „For it is clear that transhumanism is an idea whose time has come".

Conceptul de Singularitate, enunțat de același Nick Bostrom, desemnează momentul în care omenirea ar ajunge la un moment ireversibil în care condiția umană, fiind depăşită de o superinteligență artificială, care ar deveni autonomă, ar face umanitatea să fie o relicvă a istoriei, prin faptul că aceasta va fi fost deja fuzionată cu această formă de inteligență.

Nick Bostrom exprimă această convingere în felul următor:

„Superintelligence înseamnă orice formă de inteligență artificială, inspirată de o mai bună înțelegere a arhitecturilor computerizate și a algoritmilor de învățare folosiți de creierul uman, care este capabilă să depășească cele mai bune creiere umane, în practic, orice disciplină, inclusiv creativitatea științifică, înțelepciunea practică și abilitățile sociale"'.

${ }^{5}$ NBIC este un acronim care desemnează convergenţa mai multor tehnologii utilizate în scopul ameliorării perfomanțelor umane: nano-tehnologiile $(\mathrm{N})$, biotehnologiile sau bioingineriile (B), informatica (I) și științele cognitive (C).

${ }^{6}$ https://nickbostrom.com/old/transhumanism.html (consultat 04.07.2019).

7 Nick Bostrom, Declarație transumanistă, pe: https://nickbostrom.com/old/ transhumanism.html (consultat 04.07.2019). 
În mod ironic, natura umană inspiră cercetătorilor modul în care inteligența artificială, învățând de la creierul uman, va depăși originalul în toate abilităţile sale.

Pentru teologi ca Dominique Foyer, prezentul manifest se înscrie într-o inițiativă cu caracter religios, nu de tipul profețiilor biblice sau coranice, ci sub forma unor profeții autorealizatoare. Mai mult, anunțul este interpretat ca fiind în sfera fenomenelor religioase și nu a celor de natură științificăa întrucât are în vedere crearea sentimentului de adeziune la un anumit program ipotetic realizabil în viitor ${ }^{8}$.

Pentru Julien Huxley, transumanismul este o ,religie fără revelație", așa cum apare chiar în titlul lucrării sale. Dorința de a oferi omului capacitatea de a se auto-transcende prin intermediul tehnologiei şi idealul asumat de a modifica sau reconfigura umanul se înscriu într-un proiect care are în vedere conferirea unei vocaţii mântuitoare tehnologiei ${ }^{9}$. Comparația cu religiile tradiționale ne permite să afirmăm că această mișcare ideologică are capacitatea de a deveni un proiect religios. Necesitatea de a îmbunătăți, ameliora sau schimba natura umană, arată o profundă ură care se manifestă prin dorința de a o ameliora prin editare genetică, simbioză om-mașină sau transferul conștiinței într-un computer. Toate acestea ne conferă imaginea unei gnoze maniheice de sorginte tehnologică, care îşi propune modificarea sau aneantizarea umanului.

Două mari scenarii se vor contura în încercarea de a oferi nemurirea biologică sau accederea la o altă formă de nemurire prin tehnică. Prima ofertă este cea a hibridului om-mașină (inteligență artificială) prin care se oferă individului capacități corporale îmbunătățite precum nemurirea, omnisciența. Dacă primul model propus reține câteva elemente ale naturii umane pe care le compensează prin inteligența artificială, cel de-al doilea scenariu al mind uploading propune eliminarea oricărei forme de corporeitate biologică, prin faptul că încearcă să transfere spiritul individului, înțelegând prin aceasta memoria, cunoștințele, emoțiile, trăsăturile comportamentale, sub forma unor

8 Dominique FOYER, „Le transhumanisme: une religion en émergeance?”, în Revue d'éthique et de théologie morale, nr. 302, 2019, p. 78-79.

9 Cecilia CAlHeiros, „Aspiration métaphysiques et attentes eschatologiques chez les transhumanistes", în Revue d'éthique et de théologie morale, nr. 302, 2019, p. 45. 
informații numerice ce vor fi ulterior descărcate pe internet. Accederea la această rețea globală este văzută ca fiind o primă formă a transcenderii și a decorporeizării ${ }^{10}$.

Post-umanismul este etapa următoare a tranziției, având ca punct final deplasarea spiritelor umane în corpuri robotice nemuritoare și reînlocuibile. Seducția omului de către mașină își poate avea originea întro „Ruşine Prometeeană” (concept introdus de către Gunther Anders în anul 1956), desemnând prin aceasta un sentiment de inferioritate al omului în fața inteligenței tehnologiei și a performanțelor acesteia. Soluția găsită în fața umilinței de a fi declasat de către inteligența artificială este chiar dorința de a deveni noi înșine om-mașină ${ }^{11}$.

Transumanismul capătă accente maniheice prin voința de a crea noi forme ale individului, prin fuziunea om-mașină, fără a respecta demnitatea și valoarea persoanei umane. În același timp, este evidentă tentația demiurgică de a fi un alt creator al altor forme de creație pe care și le arogă cei care vor să fie la originea altor indivizii. Filosoful JeanMichel Besnier ne atrage atenția că această operă de creație arată aspirația oamenilor pentru a înlocui pe Logosul Creator, Cel Care este la originea întregii creațiii ${ }^{12}$. Acest avertisment ne obligă să analizăm în ce măsură transumanismul devine o gnoză ce se opune creștinismului, precum și interferențele dintre acestea două.

\section{Transumanismul și creștinismul. Îmbunătățirea capacităților umane și îndumnezeirea creștină}

Programul transumanist găsește ecouri și în mediile creștine, concomitent $\mathrm{cu}$ diseminarea ideilor transumaniste în mediul academic și politic. În State Unite ale Americii există în acest moment o asociație creștină transumanistă - Christian Transhumanist Association - care își propune să justifice acțiunile și cercetările transumaniste cu ajutorul noțiunilor creștine. Pentru adeziunea la această asociație este necesară consimțirea la cinci afirmații: 1) Credem că misiunea lui Dumnezeu

${ }^{10}$ Ibidem, p. 48.

${ }^{11}$ Maxime DERIAN, „Le transhumanisme: incarnation de l'hypermodernisme...ou fuite en avant fantasmatique", în Connexions, nr. 110, 2018, p. 80.

12 Jean Michel BesniER, „D'un transhumanisme mortifère d'immortalité. A propos du transhumanisme", în Presses Universitaires de France, nr. 55, 2013, p. 17. 
implică transformarea și reînnoirea creației, inclusiv umanitatea, şi că suntem chemați de Hristos să participăm la acea misiune luptând împotriva bolii, foamei, opresiunii, nedreptății și morții. 2) Căutăm creșterea și progresul de-a lungul fiecărei dimensiuni a umanității noastre: spiritual, fizic, emoțional, mental și la toate nivelurile: individ, comunitate, societate, global. 3) Noi recunoaștem știința și tehnologia ca expresii tangibile ale impulsului nostru dat de Dumnezeu de a explora și de a descoperi și ca o ieșire naturală a faptului că suntem creați în chipul lui Dumnezeu. 4) Suntem ghidați de cele mai mari porunci ale lui Iisus: "Iubiţi pe Domnul, Dumnezeul vostru, cu toată inima, sufletul, mintea și puterea voastră...și iubiți pe vecinul vostru ca pe voi înșivă". 5) Noi credem că folosirea intenționată a tehnologiei, cuplată cu urmarea lui Hristos, ne va permite să devenim mai umani în întregul domeniul de aplicare a ceea ce înseamnă a fi creaturi după chipul lui Dumnezeu ${ }^{13}$. Observăm o abordare destul de superficială a riscurilor pe care le presupune această ideologie față de creștinism. Totodată, este ușor de constatat faptul că în conținutul declarației apar două afirmații care relevă sub aspect teologic un puternic accent deist, Dumnezeu oferind un impuls pentru cunoaștere și acțiune oamenilor, lăsându-i posterior să procedeze, prin intermediul tehnologiei, la îmbunătățirea umanului. Asemenea, necesitatea creșterii capacităților spirituale, fizice, mentale și emoționale denotă o creație supusă imperfecțiuni $a b$ initio, un Creator incapabil de o creație desăvârșită. Deși manifestul amintește de Hristos, țelul urmării lui Hristos nu este mântuirea și desăvârșirea în Împărăția lui Hristos, ci o mai puternică umanizare în planul imanentului.

Teologia ortodoxă aduce o viziune în care desăvârşirea și îmbunătătirea omului nu vizează doar planul biologicului ci, mai ales, planul spiritual. Mântuirea nu este în perspectivă ortodoxă izbăvirea de natura umană și eliminarea ei maniheică, ci desăvârşirea vieții, respectând demnitatea corporalității, mai ales în plan eshatologic, așteptând învierea trupurilor.

Antropologia ortodoxă fundamentată biblic, plecând de la evenimentul creației, mărturisește o umanitate „după chipul și spre

13 Declarația de principii și acțiuni a Asociației Creștin Transumaniste, pe: https://www.christiantranshumanism.org/affirmation (consultat 04.07.2019). 
asemănarea cu Dumnezeu", o orientare ontologică a omului și a creaţiei spre Creator, precum și o dinamică a omului spre creșterea într-o și mai deplină perfecțiune și unire cu Creatorul său. Momentul căderii lui Adam consistă în acest context, așa cum teologia patristică răsăriteană spune, într-o umbrire sau întunecare a chipului lui Dumnezeu din om și nicidecum o cădere abisală, ce face imposibilă reorientarea creației și, implicit, a omului spre Dumnezeu. În acelaşi timp, accederea la perfecțiune a creștinului nu este un efort pur uman, așa cum proiectul transumanist propune, dimpotrivă, necesitatea harului lui Dumnezeu fiind absolut necesară în acest sens. Demersul creștin de îndumnezeire are ca fundament orientarea ontologică a omului spre Creatorul care imprimă omului în constituţia sa o dimensiune spirituală ce permite colaborarea cu Dăruitorul Suprem. Accederea la îndumnezeire este un dar al Creatorului, care dorește ca toți oamenii să se înscrie într-un demers filial ascultător asemenea Fiului lui Dumnezeu. Voința Tatălui este ca toată umanitatea nu doar să urmeze Fiului, ci şi să se împărtășească prin har de filiația Fiului față de Tatăl, dar la un alt nivel, nu ontologic, ci haric. Transumanismul, în mod contrar, nu speră la o unire cu Transcendentul, ci dorește crearea acestuia de către om prin evenimentul singularității, printr-o entitate tehnologică creată de către om, care pune umanitatea în fața unei creații care depăşește ,simpla umanitate” prin posibilităţile și capacitățile pe care le are.

Jean Claude Larchet ne încredințează că îndumnezeirea poate fi o formă de îmbunătăţire sau ameliorare, deoarece, prin harul primit, omul dobândește calități divine care nu îi sunt proprii prin natura umană, care îl fac să depășească condiția umană simplă prin faptul că oferă umanului ceva ce depășește forțele lui proprii, inerente naturii ${ }^{14}$. Măreția mântuirii creștine rezidă în faptul că omul, prin primirea harului și prin unirea cu Dumnezeu, nu se mai supune nicidecum condiţionalităţilor impuse de legile naturii, depăşindu-le pe acestea prin Hristos. În mod practic, materia nu rămâne pentru creștin o lege oarbă a supunerii față de ciclicitatea ei în univers sau o limitare a omului în planul imanent, precum observăm că se întâmplă în cazul transumanismului.

14 Jean Claude LARCHET, „La divinisation comme projet et modèle chrétien du perfectionnement et de l'augmentation de l'homme", în Revue d'éthique et de théologie morale, nr. 286, 2015, p. 186. 
Îndumnezeirea firii umane este realizată inițial și integral în persoana divino-umană a Mântuitorului Hristos. Doar o persoană care transcende ființial condiția umană din eternitate și pentru eternitate poate oferi în dar creaturii remediul propriei căderii și perfecțiunea totală, asumând umanitatea pentru a o vindeca și a o ridica din neputință. Orice formă de zeitate pe care omului și-ar construi-o prin forțele proprii și prin tehnologie s-ar înscrie în aceeași condiție de creatură supusă inevitabil statului de obiect al operei unei alte entități. Prin Hristos, natura umană asumată de către Acesta primește prin unirea deplină în Ipostasul preexistent al Fiului lui Dumnezeu unirea cu Sfầnta Treime și prin acest act întreaga umanitate participă în potență la o unire deplină cu Dumnezeu, la care este chemată să acționeze, impulsionată fiind de harul divin. Îmbunătățirea biologiei umane sau modificarea ei prin tehnologie nu poate însemna o izbăvire a omului sau o transcendere reală a condiției de creatură, nici propria îndumnezeire cucerită individual, fără ajutorul lui Dumnezeu. În mod concret, dorința de a dobândi propria mântuire sau purcederea la o formă de existență care să se asemene cu cea a lui Dumnezeu se revelează a fi încă o dată visul inspirat de diavol al lui Adam de a fi „dumnezeu” fără Dumnezeu, prin forțele proprii.

\section{Oportunități și riscuri. Etică și responsabilitate}

Progresul bioingineriilor permite astăzi o ameliorare la nivel genetic, neuronal, prin intermediul medicamentelor stimulatoare sau la nivel fiziologic, prin atașarea unor proteze care, prin constituția lor, sporesc forțele oamenilor. Concret, modificările umanului vizează în principal trei tipuri de îmbunătătiiri: moral - prin medicamente, genetice sau fiziologice și prin tehnologie. Trebuie precizat că există o diferență notabilă între ameliorarea umanului în ceea ce privește sporirea capacităților și forțelor oamenilor și asigurarea unei terapii medicale capabilă de readucere la starea inițială, anterioară apariției unei maladii.

Modificarea genomului uman poate fi transmisibilă urmașilor, de unde și responsabilitatea pe care aceasta o implică faţă de urmașii care se vor găsi în situația de a fi obiectul unor manipulări genetice incitate de un individualism ce privește pe subiectul care decide iresponsabil pentru viitor transmiterea unor gene modificate. În același sens, programarea genetică a copilului și modificarea embrionului devine o atingere gravă a 
demnității copilului, precum și o lipsă de responsabilitate față de viitorul incert al copilului.

Am putea spune că omul se înscrie într-un demers de actor asemenea lui Dumnezeu - Playing God - așezându-se în locul lui Dumnezeu. Un alt risc inevitabil este legat de posibilitatea oferită de tehnică de a deveni, cu ajutorul tehnicilor genetice, creatorul unei alte persoane fără ca aceasta să se poată opune demersului, iar prin faptul că doar unul din cei doi subiecți acţionează, nu se respectă principiul reciprocității ${ }^{15}$.

Putem identifica și alte riscuri legate de o puternică medicalizare a societății în vederea obținerii de performanțe deosebite. Statisticile arată că un număr important de studenți din Statele Unite au apelat la substanțe psiho-stimulatoare în vederea obținerii unor performanțe îmbunătățite (între 6,9\% și 16,2\% au utilizat astfel de stimulatori, o frecvență de utilizare mai scăzută fiind înregistrată în Europa $\left.{ }^{16}\right)$.

De asemenea, creșterea capacităților fizice, morale și intelectuale ale omului prin tehnologie cere eforturi financiare foarte mari, însă dilema morală este creată de imposibilitatea accesului la astfel de modalități de dezvoltare pentru toate persoanele. Prin aceasta se crează premisele unei separații la nivel social între cei care au depășit umanul și cei perimați, care rămân la statura „,animalică” a omului nedezvoltat. Separațiile sociale de acest tip vor genera cu siguranță un nou tip de apartheid uman - postuman, precum și unele conflicte evidente între cele două tipuri de umanităţi.

\section{Concluzii}

Teologia mărturisește o valoare inegalabilă a persoanei umane, prin caracterul dihotomic al ființei umane, material și spiritual, o demnitate deosebită ce reiese din modul creării lui, dar și o orientare ontologică a acestuia, prin ,chipul lui Dumnezeu din om” orientat către Creator. Toate dilemele antropologice și bioetice enunțate anterior ne

15 Karsten LeHMNKUHLER, „La théologie face à l'amélioration de l'homme”, în Revue d'éthique et de théologie morale, nr. 286, 2015, p. 135.

16 Bernard BAERTSCHI, „Human Enhancement: les principaux enjeux éthique”, în Revue d'éthique et de théologie morale, nr. 286, 2015, p. 13. 
îndreptățesc să afirmăm că transumanismul se înscrie într-un demers care poate duce la o limitare sau alienare a existenței umane, pierzând o referință autentică spre transcendent. În mod evident, vorbim despre două concepții antropologice şi soteriologice diferite. Încheiem acest scurt excurs despre evaluarea transumanismului prin cuvintele Mântuitorului Hristos: „Şi cine dintre voi, îngrijindu-se, poate să adauge staturii sale un cot?" (Lc. 12, 25).

\section{Referinţe bibliografice:}

1. BAERTSCHI, Bernard, „Human Enhancement: les principaux enjeux éthique", în Revue d'éthique et de théologie morale, nr. 286, 2015, p. 923;

2. BESNIER, Jean Michel, „D'un transhumanisme mortifère d'immortalité. A propors du transhumanisme", în Presses Universitqires de France, nr. 55, 2013, p. 13-23;

3. CAlHEIROS, Cecilia, „Aspiration métaphysiques et attentes eschatologiaues chez les transhumanistes", în Revue d'éthique et de théologie morale, nr. 302, 2019, p. 43-57;

4. DERIAN, Maxime, „Le transhumanisme: incarnation de l'hypermodernisme...ou fuite en avant fantasmatique", în Connexions, nr. 110, 2018, p. 73-86;

5. FOYER, Dominique, „Le transhumanisme: une religion en émergeance?”, în Revue d'éthique et de théologie morale, nr. 302, 2019, p. 73-86;

6. https://humanityplus.org/

7. https://iatranshumanisme.com

8. https://nickbostrom.com

9. https://www.christiantranshumanism.org

10. Jousset-COUTURIER, Beatrice, Le transhumanisme, Paris, Edit. Eyrolles, 2016;

11. LARCHET, Jean Claude, „La divinisation comme projet et modèle chrétien $\mathrm{du}$ perfectionnement et de l'augmentation de l'homme", în Revue d'éthique et de théologie morale, nr. 286, 2015, p. 181-197;

12. LEHMNKUHLER, Karsten, „La théologie face à l'amélioration de l'homme", în Revue d'éthique et de théologie morale, nr. 286, 2015, p. 123-140. 